\title{
TEACHER TRAINING IN THE CONTEXT OF INCLUSIVE EDUCATION: METHODOLOGICAL DIMENSION
}

\author{
Janis Dzerviniks \\ Rezekne Academy of Technologies, Latvia
}

\begin{abstract}
In accordance with the current pedagogical principles, the view is emphasized that education should be individual-oriented, socially responsible, and inclusive. Inclusive education is focused on providing education for all children, regardless of their needs. The article deals with the emphases of inclusive education in the teacher training; evaluation of the study program „Teacher” is carried out on the basis of the criteria developed. The explored prior experience is a basis to improve methodology, content, and organization of the pedagogical study programs. It is essential that the prospective teachers would receive qualitative methodological support for the implementation of inclusive education.
\end{abstract}

Keywords: evaluation, inclusive education, methodological dimension, study program, teacher training.

\section{Introduction}

Inclusion is one of the current issues in education around the world. This process is based on the principle that schools shall educate all children, regardless of type, degree, and severity of development disability or any other social, emotional, cultural, or linguistic differences (Kondrova, Orska, Rozenfelde, 2012). To ensure successful inclusion of children in the educational system and secure their further development, the teachers have to be professionally trained, proficient in the issues of inclusive education in order to be able to recognize each pupil's individual needs. That would enable to identify means for promoting every child's personal growth.

Teacher training in Rezekne has started in 1925. Rezekne Academy of Technologies continues the traditions of teacher training implementing professional bachelor study program "Teacher". The program is internationally accredited for the maximal term of 6 years and is included in the study direction "Education, pedagogy, and sports".

In the research, the study program "Teacher" was analyzed in accordance with the principles of inclusive education.

The aim of the research: to propose emphases of inclusive education for the teacher training and to evaluate the study program "Teacher" in the context of inclusive education. 
Janis Dzerviniks. Teacher Training in the Context of Inclusive Education: Methodological Dimension

Methods of the research: analysis and interpretation of scientific literature on the topic of the research; analysis and interpretation of documents and materials of professional bachelor study program "Teacher".

\section{Emphases of inclusive education in the teacher training}

In the teacher's profession, it is important to realize that every single individual is a constituent part of a society, providing his/her contribution to the value system and taking responsibility for the common result by his/her activities. Thus it is significant for everyone to be a good person, positive and eager to do good (Ošeniece, 2010). In a democratic society, the main value is an individual. Each person's unique individuality and dignity are important. In the teacher's work, it is essential to accept each pupil as he/she is, with his/her strengths and weaknesses, and to ground teaching on the pupils' positive qualities, creating awareness of an individual as a value. In the study process, developing of the students' awareness of an individual as an active, free, independent, and responsible entity by recognition of his/her freedom and selfrealization, should be emphasized.

Inclusive education offers equal opportunities for all children and young people, regardless their needs and abilities, financial situation or social status, race, nationality, gender, religion, and political beliefs, health conditions, place of residence, and occupation, in the environment that is accessible, respectful and supportive through participation in the education process and achieving results (Iekļaujošā izglītība, 2013; Education White Paper 6, 2001). Inclusive education is focused on providing education for all children, regardless of their needs. The study process and pedagogical practice should be organised in the way, the students would be able to explore, analyse and assess diverse personal qualities of the schoolchildren and their dynamics, to effectively apply a variety of pedagogical approaches in heterogeneous groups, to perform the pedagogical activities not just independently, but as well in cooperation with other education professionals and the children's parents, to be aware of the responsibility for their own education and professional development.

The students during the studies and professional pedagogical practice shall form an understanding of the educational establishment as a child-friendly environment. The main criteria of evidence are:

- premises and equipment appropriate for schoolchildren; implementation of an individual approach to children;

- the educational establishment is favorable, supportive, and focused on mutual understanding; 
- pupils and parents are informed of the school's activities and education process;

- the personnel is professional and aware of children's rights;

- the management is responsive, welcoming towards the schoolchildren and parents;

- a variety of extracurricular education activities are provided in the school;

- a healthy lifestyle of the schoolchildren is encouraged (Bērniem draudzīga skola, 2010; Education White Paper 6, 2001).

The teacher training program shall be implemented based on the student's activity - grounded paradigm, which is centred on the belief that knowledge is being constructed by those who learn and develop knowledge in the process of acquiring experience. The student is required to study the information, test new ideas, solve current professional problems, and find new answers in different situations. By learning to solve problems, the students investigate the problem situations, and this activity develops thinking and motivates learning. The studies are based on the belief that knowledge is constructed on the basis of experience and mental activity. The role of structured prior knowledge is essential. The student creates new knowledge, building it on the own experience, with support of the lecturer and implementing diverse activities.

The professional bachelor study program „Teacher” of Rezekne Academy of Technologies was evaluated according to the certain criteria in five dimensions:

- methodological;

- $\quad$ personal and professional;

- environmental;

- regulatory;

- $\quad$ social (table 1).

In the article, the program's evaluation in the methodological dimension is emphasised.

The criteria were developed within the framework of the European Social Fund project „Development and implementation of the support programs for creation of the support system for the youth under the risk of social exclusion" (No. 2010/0328/1DP/1.2.2.4.1./10/IPIA/VIAA/002). The teachers of Latvian higher education establishments, implementing pedagogy study programs, participated in the project (Atbalsta programmu izstrāde ..., 2012). 
Janis Dzerviniks. Teacher Training in the Context of Inclusive Education: Methodological Dimension

Table 1 Criteria for evaluation of the study program ,Teacher”

(Atbalsta programmu izstrāde ..., 2012; Development of a set of indicators ..., 2009; Teacher Education for Inclusion ..., 2012)

\begin{tabular}{|c|c|}
\hline Dimension & Criteria \\
\hline \multirow[t]{3}{*}{ Methodological } & $\begin{array}{l}\text { Incorporation of the ideas of inclusive education in the program } \\
\text { description, objectives, tasks, and learning outcomes }\end{array}$ \\
\hline & Incorporation of inclusion technologies in the study program \\
\hline & $\begin{array}{l}\text { Implementation of integrated, inclusive approach in the study } \\
\text { process }\end{array}$ \\
\hline \multirow{3}{*}{$\begin{array}{l}\text { Personal and } \\
\text { professional }\end{array}$} & Understanding of an individual as a value \\
\hline & Broadening of an individual responsibility options \\
\hline & Integration of the values of inclusive education \\
\hline \multirow[t]{3}{*}{ Environmental } & Accessibility of physical and virtual environment to all \\
\hline & Friendly environment to all education entities \\
\hline & Environment opened to creativity and critical thinking \\
\hline \multirow[t]{2}{*}{ Regulatory } & $\begin{array}{l}\text { Reflection of the human rights, tolerance, and empathy principles } \\
\text { in the regulatory documents of the study program and the course } \\
\text { content }\end{array}$ \\
\hline & $\begin{array}{l}\text { Implementation of the human rights, tolerance and empathy } \\
\text { principles in teaching practice }\end{array}$ \\
\hline \multirow[t]{3}{*}{ Social } & Variety of social skills encouraging the inclusion \\
\hline & Equal and equitable cooperation between the educational entities \\
\hline & Problem solving literacy \\
\hline
\end{tabular}

\section{Evaluation of the study program "Teacher" in the methodological dimension}

In view of the methodological dimension, it is essential to analyze the incorporation of inclusive education ideas in the program description, objectives, tasks, and learning outcomes. The program for teacher training aims to prepare teachers, who are proficient in the educational science theories and in the field of their specialisation, who have mastered their basic professional competences in cooperation with the employers, who are able to plan, implement and evaluate teaching activities, and who are focused on the lifelong learning and professional development (2.līmeña profesionālās augstākās ..., 2010). The objective and tasks as well point to the fact that students learn scientific theories, the concepts and rules of the education field, wherein the inclusive education has an essential position. The theoretical training must be linked to the practice and, therefore, the objective and the tasks reflect cooperation with the employers, the directors and the teachers of the comprehensive school in a status of mentors for the practical work and reviving the theoretical knowledge in the practical pedagogical work with the 
schoolchildren. The teacher is obliged to continuously improve their professional competence. The objective of the study program points to the training of teachers, who are focused on continuous professional development. The undergraduate teacher education in the view of inclusive education policies can be considered as a basis for professional development and progress.

One of the tasks of the study program is to build the students' skills to plan, organize and evaluate teaching activities, to implement pedagogical interaction, cooperation with the schoolchildren, their parents, other teachers, and the society. Cooperation and teamwork play an important role in the teacher's work, since an inclusive teaching process is based on positive interaction and cooperation. Implementation of the study program is focused on the acquisition of skills to interact and cooperate with parents and the family, which is an important element in parental supportive involvement in the children's educational process. Inclusive education compels the teachers to work in team, in mutual cooperation among themselves and with the assisting personnel, in cooperation with educational experts, professionals of various sectors, and this idea is highlighted in the tasks of the study program.

The tasks of the study program are also intended to contribute to the students' independent study activities, raising awareness about human development and its unity with the social and natural environment, encourage students for innovative and creative personal development for the work in a democratic and humane school environment. The study process requires formation of the students' awareness of the pupils' diversity, its value in the educational process, and the use of diversity as a resource for training and educational tasks. The idea of a democratic and humane school is related with an understanding of the school as a group, whose members have qualities of freedom, responsibility, and independence, and which is characterized by an active, creative work and mutual respect.

The study program has the task to develop the students' scientific research skills in the field of pedagogy, carrying out independent researches in pedagogy and methodology. Consequently, the students carry out a diverse range of scientific research during the studies, preparing the course papers and diploma projects, and present the results in the academic groups and student conferences. The study program is designed to develop the students' ability to formulate and analyze the problems in education and in the teachers' work, to make reasoned decisions for problem solution, to organize independently further development of their professional competences. These aspects are important for inclusive teaching work.

The planned learning outcomes are included in the description of the study program, indicating the activities the graduate of the study program, owner of 
the professional bachelor's degree in education and the teacher professional qualification is able to perform.

The intended learning outcomes of the program contain the core values of inclusive education: recognition of the schoolchildren's diversity, support for all schoolchildren, work together with the assisting personnel, effective communication with students, their parents, other professionals in order to ensure the pupils' needs, addressing different problems, based on a pedagogical models and approaches, respect of cultural diversity of pupil and use of this diversity as a resource in the educational process, as well as continuous personal professional development (Profesionālās augstākās izglītības ..., 2011). The study program is designed in accordance with the professional standard "Teacher" and the regulations of the Republic of Latvia on the standard of the second - level professional higher education. It is structured into several parts: general courses (humanities and social sciences courses; courses that develop basic social, communicative, and organizational skills), basic theoretical courses and information technology courses, professional specialization courses (includes study modules according to the qualifications), elective courses, practice, and state examinations.

The study program incorporates the courses that reveal the core values of inclusive education and provide development of knowledge, skills and attitudes, which is the basis for the teacher's work in inclusive education. During the studies, according to the study specialization, the students learn the subject methodology courses, which include issues on application of different learning approaches, models, methods, and forms, elaboration and differentiation of the curriculum and teaching materials.

\section{Conclusions}

1. Education should be individual-oriented, socially responsible, and inclusive. Inclusive education is focused on providing education for all children, regardless of their needs.

2. Evaluation of the study programs in accordance with the principles of inclusive education is one of the steps to identify the experience of inclusion that should become the change agent to improve the methodology, content, and organization of the study programs. Prospective teachers have to receive quality methodological support to implement an inclusive approach in education.

3. The study programs in the context of inclusive education are evaluated in dimensions: methodological, personal and professional, environmental, regulatory, social. Criteria for evaluation of the study programs in the methodological dimension can be following: 
- incorporation of the ideas of inclusive education in the programs description, objectives, tasks, and learning outcomes;

- incorporation of inclusion technologies in the study programs;

- implementation of integrated, inclusive approach in the study process.

4. Methodology, content, and organization of the professional bachelor study program „Teacher” at Rezekne Academy of Technologies is inherently focused on preparation of the inclusive teacher, however, there are visible possibilities for the program improvement:

- the core values of inclusive education shall be emphasised more specifically in the terms of the tasks and the learning outcomes of the program;

- the principles of human rights, tolerance and empathy shall be more emphasised in the content of courses, methodological instructions for teaching practice, and in the regulatory documents for the studies.

5. At the level of educational policy, content of the teacher's professionalism is determined by the professional standard. It provides a common vision that can be used not only for the professional training of teachers in the higher education institutions, but as well in planning, managing, and evaluating professional development in the continuous education. The public interest would be to make the teacher's professional standard sufficiently flexible and opened to change, thus providing a modern education management and incorporating current trends in education and in the profession, including accents of an inclusive teaching and principles of human rights, tolerance and empathy in the teacher's work.

\section{References}

2.lìmeņa profesionālās augstākās izglìtības bakalaura studiju programma „Pamatizglìtības skolotājs sākumskolā” (2010). Atkārtotas akreditācijas materiāli. Rēzekne: Rēzeknes Augstskola, Retrieved 15.12.2015. from: http://www.aiknc.lv/lv/prog_view.php? id $=6263$.

Atbalsta programmu izstrāde un īstenošana sociālās atstumtības riskam paklıuto jauniešu atbalsta sistēmas izveidei (2012). Rīga: ESF, Latvijas Universitāte. Retrieved 04.11.2015. from: http://www.lu.lv/par/projekti/es/2007-2013/esf/socialaatstumtiba/ jauniesi/.

Bērniem draudzìga skola (2010). Downloaded 16.12.2015. from: http://www.lm.gov.lv/ upload/berns_gimene/bernu_tiesibas/projekti/bdsk_buklets.pdf.

Development of a set of indicators - for inclusive education in Europe (2009). European Agency for Development in Special Needs Education, p.45. Downloaded 16.12.2015. from: https://www.european-agency.org/sites/default/files/development-of-a-set-ofindicators-for-inclusive-education-in-europe_Indicators-EN-with-cover.pdf. 
Janis Dzerviniks. Teacher Training in the Context of Inclusive Education: Methodological Dimension

Education White Paper 6 (2001). Special Needs Education. Building an inclusive education and training system. Retrieved 05.11.2015. from: http://www.education.gov.za/ LinkClick.aspx?fileticket $=\mathrm{gVFccZLi} / \mathrm{tI}=$

Ieklaujoša izglìtība (2013). Rīga: Izglītības attīstības centrs. Retrieved 15.12.2015. from: http://www.iac.edu.lv/seminari/ieklaujosa-izglitiba/.

Kondrova, A., Orska, R., \& Rozenfelde, M. (2012). Pedagogiskā personāla gatavība ieklaujošās izglītības realizācijai vispārējās izglītības iestādē. SOCIETY. INTEGRATION. EDUCATION. Proceedings of the International Scientific Conference, v. II.Rēzekne: Rēzeknes Augstskola, 142-153.

Ošeniece, G. (2010). Vērtības skolā jeb skolas vērtība. Retrieved 15.12.2015. from: http://www.tavaskola.lv/node/283.

Profesionālās augstākās izglītības bakalaura studiju programmas „Skolotājs” ìstenošanas aspektu apraksts (2011). Rēzekne: Rēzeknes Augstskola.

Teacher Education for Inclusion. Profile of Inclusive Teachers (2012). Edited by: Amanda Watkins, European Agency for Development in Special Needs Education, p.50. Downloaded 16.12.2015. from: https://www.european-agency.org/sites/ default/files/Profile-of-Inclusive-Teachers.pdf. 